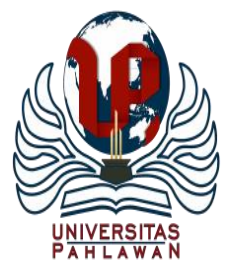

Edukatif : Jurnal Ilmu Pendidikan Volume 3 Nomor 4 Tahun 2021 Halm 2294 - 2304

EDUKATIF: JURNAL ILMU PENDIDIKAN

Research \& Learning in Education

https://edukatif.org/index.php/edukatif/index

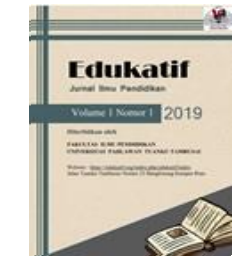

\title{
Peningkatan Hasil Belajar Siswa dengan Menggunakan Model Problem Based Learning pada Pembelajaran Tematik
}

\author{
Emenina Br Tarigan ${ }^{1 凶}$, Ester J. Simarmata ${ }^{2}$, Antonius Remigius Abi ${ }^{3}$, Darinda Sofia Tanjung ${ }^{4}$ \\ Pendidikan Guru Sekolah Dasar, Universitas Katolik Santo Thomas, Medan, Indonesia ${ }^{1,2,3,4}$ \\ E-mail : Emeninabrtarigan14@gmail.com ${ }^{1}$, ejulinda@gmail.com² ${ }^{2}$, antoniusremiabis3@gmail.com ${ }^{3}$, \\ darinda_tanjung@ust.ac.id ${ }^{4}$
}

\begin{abstract}
Abstrak
Penelitian ini bertujuan untuk meningkatkan hasil belajar siswa pada tema daerah tempat tinggalku melalui model PBL di kelas IV SD Negeri 040550 Mardingding T.P 2020/2021. Teknik pengumpulan data melalui tes dan lembar pengamatan. Hasil Penelitian ini menunjukkan adanya peningkatan hasil belajar siswa pada tema daerah tempat tinggalku kelas IV SD Negeri 040550 Mardingding. Hal ini terbukti dari hasil penelitian yang dilakukan pada prates siswa yang mendapat nilai tuntas sebanyak 9 orang atau 30\% sedangkan siswa yang tidak tuntas sebanyak 21 orang atau $70 \%$. Maka dilanjutkan penelitian pada siklus I siswa yang mendapat nilai tuntas sebanyak 14 siswa atau 47\% sedangkan siswa yang tidak tuntas sebanyak 16 siswa atau 53\%, maka terjadi peningkatan pada siklus I dibandingkan pada prates. Akan tetapi belum memenuhi kategori ketuntasan yang telah di tentukan. Maka dilanjutkan penelitian pada siklus II yaitu siswa yang mendapat nilai tuntas sebanyak 26 siswa atau $87 \%$ sedangkan siswa yang tidak tuntas sebanyak 4 siswa atau $13 \%$, maka terjadi peningkatan pada siklus II dibandingkan pada siklus I dan telah memenuhi ketuntasan yang sudah ditentukan.

Kata Kunci: Hasil Belajar Siswa, Model Problem Based Learning.
\end{abstract}

\begin{abstract}
This study aims to improve student learning outcomes on the theme of the area where I live through the PBL model in grade IV SDN 040550 Mardingding T.P 2020/2021. Data collection techniques through tests and observation sheets. The results of this study indicate an increase in student learning outcomes on the theme of the area where I live in class IV SDN 040550 Mardingding. This is evident from the results of research conducted on pre-test students who got a complete score of 9 people or $30 \%$ while students who did not complete as many as 21 people or 70\%. Then continued research in the first cycle of students who got a complete score of 14 students or 47\% while students who did not complete as many as 16 students or 53\%, then there was an increase in the first cycle compared to the pretest. However, it does not meet the specified completeness category. Then continued research in cycle II, namely students who got a complete score of 26 students or $87 \%$ while students who did not complete as many as 4 students or 13\%, then there was an increase in cycle II compared to cycle I and had met the predetermined completeness.
\end{abstract}

Keywords: Student Learning Outcomes, Problem Based Learning.

Copyright (c) 2021 Emenina Br Tarigan, Ester J. Simarmata, Antonius Remigius Abi, Darinda Sofia Tanjung

$\triangle$ Corresponding author

Email: Emeninabrtarigan14@gmail.com

DOI : https://doi.org/10.31004/edukatif.v3i4.1192

ISSN 2656-8063 (Media Cetak)

ISSN 2656-8071 (Media Online) 
2295 Peningkatan Hasil Belajar Siswa dengan Menggunakan Model Problem Based Learning pada Pembelajaran Tematik - Emenina Br Tarigan, Ester J. Simarmata, Antonius Remigius Abi, Darinda Sofia Tanjung

DOI: https://doi.org/10.31004/edukatif.v3i4.1192

\section{PENDAHULUAN}

Pendidikan merupakan salah satu cara untuk membenahi, meningkatkan mutu hidup seseorang. Dengan pendidikan seseorang dapat meningkatkan potensi yang ada pada dirinya. Namun pendidikan tidak hanya dimaksudkan untuk mengembangkan pribadi semata melainkan juga sebagai akar dari pembangunan suatu negara.

Peran lembaga pendidikan sangat penting guna menyokong dan membantu terbentuknya sumber daya yang potensial. Pendidikan melalui lembaga formal merupakan cara yang sangat tepat untuk meningkatkan kualitas pembelajaran yang dilakukan oleh guru. Guru merupakan salah satu unsur dalam proses belajar mengajar yang dituntut memiliki kemampuan dalam segala hal yang berkaitan pelaksanaan pengajaran di kelas.

Guru memegang peranan penting dalam keberhasilan siswanya, walaupun sebaik apa kurikulum yang diterapkan, sarana prasarana terpenuhi, tetapi bila guru belum berkualitas maka proses belajar mengajar belum dikatakan baik. Oleh sebab itu guru bukan hanya mengajar melainkan mempunyai makna sadar dan kritis terhadap mengajar dan menggunakan kesadaran dirinya untuk mengadakan perubahan-perubahan dan perbaikan pada proses pembelajarannya. Seorang guru ideal akan mampu bertindak dan berfikir kritis dalam menjalankan tugasnya secara profesional dan dapat menemukan alternatif yang harus diambil dalam proses belajar mengajar guna tercapainya tujuan pembelajaran itu sendiri.

Pembelajaran yang ideal merupakan pembelajaran yang mampu mendorong kreativitas anak secara keseluruhan, membuat siswa aktif, mencapai tujuan pembelajaran secara efektif dan berlangsung dalam kondisi menyenangkan. Selain itu pembelajaran ideal berarti tercapainya tujuan dari suatu pembelajaran.

Namun demikian upaya untuk meningkatkan mutu pendidikan tidak semua bergantung pada faktor guru saja tetapi berbagai faktor lainnya juga berpengaruh untuk menghasilkan keluaran atau output proses pengajaran yang bermutu, meskipun pada hakikatnya guru adalah salah satu unsur utama dalam sistem pendidikan yang sangat mempengaruhi pendidikan.

Pendidikan juga merupakan usaha sadar dan terencana untuk mewujudkan suasana belajar dan proses pembelajaran agar siswa secara aktif mengembangkan potensi dirinya. Keberhasilan suatu pendidikan sangat terkait dengan hasil belajar siswa. Hasil belajar merupakan indikator dari keberhasilan siswa dalam pembelajaran. Melihat begitu pentingnya pendidikan dalam meningkatkan sumber daya manusia, peningkatan mutu pendidikan merupakan hal yang wajib guna menjawab perubahan zaman maka untuk itu seseorang harus belajar.

Belajar merupakan suatu aktivitas yang berlangsung dalam interaksi aktif antara seseorang dengan lingkungan, dan menghasilkan perubahan-perubahan tingkah laku, pengetahuan, pemahaman, dan keterampilan. Dengan belajar diharapkan adanya perubahan positif dari dalam diri siswa sehingga mampu menyelesaikan masalah dalam hasil belajar yang telah dilakukan. Tanjung (2016:. 73) mengatakan bahwa "Belajar merupakan hal yang komplek. Komplek belajar tersebut dapat dipandang dari dua aspek, yaitu dari siswa dan guru. Dari segi siswa, belajar dialami sebagai suatu proses. Siswa mengalami proses mental dalam menghadapi tumbuhan, manusia dan bahan yang telah terhimpun dari buku-buku pelajaran. Dari segi guru, proses belajar tersebut tampak sebagai perilaku belajar tentang suatu hal".

Dalam pembelajaran Sekolah Dasar (SD) ada beberapa mata pelajaran yang diterapkan. Mata pelajaran IPS, PPKn, dan Bahasa Inonseia. Pembelajaran di Sekolah Dasar sangat penting untuk mengajarkan siswa agar dapat berinteraksi baik dengan lingkungan masyarakat. Salah satu materi pembelajaran yang mengarahkan siswa untuk berinteraksi dengan lingkungan sekitar adalah pembelajaran IPS merupakan pembelajaran yang sangat penting bagi siswa yang berkaitan langsung dengan interaksi siswa dengan lingkungannya yang beragam situasi dan kondisi. Pada dasarnya pembelajaran yang di ajarakan oleh guru 
2296 Peningkatan Hasil Belajar Siswa dengan Menggunakan Model Problem Based Learning pada Pembelajaran Tematik - Emenina Br Tarigan, Ester J. Simarmata, Antonius Remigius Abi, Darinda Sofia Tanjung

DOI: https://doi.org/10.31004/edukatif.v3i4.1192

bertujuan untuk mengembangkan kemampuan siswa menggunakan penalaran dalam mengambil keputusan dan berusaha membantu siswa dalam memecahkan permasalahan yang dihadapi sehingga akan menjadikannya semakin mengerti dan memahami lingkungan sosial masyarakat.

Di dalam proses pembelajaran guru harus menguasai materi yang diajarkan dan cara menyampaikannya. Atau upaya untuk menciptakan lingkungan kelas yang lebih baik, sehingga siswa dapat belajar secara efektif dan efisien supaya tujuan pembelajaran dapat tercapai. Salah satu tindakannya guru memiliki berbagai strategi/model pembelajaran untuk meningkatkan keaktifan siswa saat pembelajaran berlangsung.

Berdasarkan hasil observasi dan wawancara dengan guru kelas IV SD 040550 Mardingding. Kenyataan di lapangan pelajaran IPS, PPKn, dan Bahasa Indonesia masih dianggap sebagai pelajaran yang membosankan atau dianggap sepele oleh sebagian besar siswa. Kenyataan ini semakin diperburuk dengan model mengajar yang dipakai oleh sebagian besar guru masih memakai model konvensional. Model konvensional merupakan model dimana guru memegang peranan utama dalam menentukan isi dan langkah-langkah dalam menyampaikan materi kepada siswa. Sehingga keaktifan siswa dalam mengikuti kegiatan belajar dan mengajar berkurang dan hanya bergantung pada guru. Model ini hanya berfokus pada aktivitas siswa yang terbatas pada kegiatan membaca bersuara, mendengarkan ceramah guru, menjawab pertanyaan-pertanyaan guru, menyalin rangkuman atau ringkasan, dan mengerjakan soal-soal atau latihan yang terdapat dalam buku teks. Begitu juga dengan amanat kurikulum 2013 agar pada kegiatan pembelajaran menggunakan beberapa model pembelajaran yang dapat mengoptimalkan pengembangan potensi peserta didik tidak terlaksana. Sehingga hasil belajar siswa pada tema "Daerah Tempat Tinggalku" masih tergolong rendah. Dari hasil data dokumen observasi di kelas IV SD Negeri 040550 Mardingding Kecamatan Mardingding, dapat dilihat rendahnya hasil belajar siswa pada tabel di bawah ini.

Tabel 1 Data Dokumen Hasil Observasi A wal

\begin{tabular}{lcccl}
\hline \multirow{2}{*}{ Mata Pelajaran } & $\begin{array}{c}\text { Nilai } \\
\text { KKM }\end{array}$ & $\begin{array}{c}\text { Jumlah } \\
\text { Siswa }\end{array}$ & $\begin{array}{c}\text { Presentase } \\
(\boldsymbol{\%})\end{array}$ & $\begin{array}{l}\text { Keterangan } \\
\text { Ketuntasan }\end{array}$ \\
\hline IPS & $>70$ & 12 & $40 \%$ & Tuntas \\
\hline & $<70$ & 18 & $60 \%$ & Tidak Tuntas \\
\hline PPKn & $>70$ & 10 & $33,3 \%$ & Tuntas \\
\hline Bahasa Indonesia & $>70$ & 20 & $66,7 \%$ & Tidak Tuntas \\
\hline & $<70$ & 10 & $33,3 \%$ & Tuntas \\
\hline
\end{tabular}

Peneliti memfokuskan perhatian pada siswa kelas IV SD 040550 Mardingding, karena permasalahan yang akan diteliti, oleh peneliti yang ditemukan di kelas tersebut. Kelas tersebut memiliki permasalahan hasil belajar rata-rata kelas pada mata pelajaran IPS, PPKn, dan Bahasa Indonesia dari 30 siswa yang rendah. Hal ini dapat dilihat berdasarkan nilai rata-rata pada tema daerah tempat tinggalku kelas IV yang mencapai nilai (KKM). Pada pembelajaran IPS yang tidak tuntas 18 siswa atau 60\% dan yang tuntas 12 siswa atau $40 \%$ yang mencapai KKM, pada pembelajaran PPKn yang tidak tuntas 20 siswa atau 66,7\% dan yang tuntas 10 siswa atau 33,3\% yang mencapai KKM, pada pembelajaran Bahasa Indonesia yang tidak tuntas 20 siswa atau 66,7\% dan yang tuntas 10 atau 33,3\% yang mencapai KKM. Data ini peneliti dapatkan setelah melakukan wawancara dengan guru di sekolah tersebut. (1) rendahnya prestasi belajar siswa disebabkan oleh kurangnya semangat siswa dalam pembelajaran. (2) tidak semua siswa mempunyai buku pegangan atau buku paket. (3) model mengajar guru yang masih berkisar pada ceramah, tanya jawab serta penugasan. (4) proses pembelajaran masih didominasi oleh guru. 
2297 Peningkatan Hasil Belajar Siswa dengan Menggunakan Model Problem Based Learning pada Pembelajaran Tematik - Emenina Br Tarigan, Ester J. Simarmata, Antonius Remigius Abi, Darinda Sofia Tanjung

DOI: https://doi.org/10.31004/edukatif.v3i4.1192

Untuk mengatasi permasalahan tersebut, maka perlu diupayakan pembaharuan model pembelajaran. Dalam hal ini, peneliti tertarik untuk melakukan penelitian menggunakan model pembelajaran Problem Based Learning (PBL). Model pembelajaran problem based learning (PBL) merupakan model pembelajaran berbasis masalah, dimana siswa bekerja dalam kelompok, mereka saling membantu dalam mengatasi berbagai persoalan atau masalah yang diberikan guru sehingga mereka saling mengerti dan memahami pelajaran tersebut.

\section{METODE PENELITIAN}

Penelitian ini dilakukan di SD Negeri 040550 Mardingding Kec. Mardingding Tahun Pembelajaran 2020/2021, yang beralamat Jln. Kutacane-Tigabinanga, Desa Mardingding, Kecamatan MardingdingKabupaten Karo. Pendekatan yang digunakan dalam penelitian ini adalah pendekatan campuran. Pendekatan campuran merupakan gabungan dari pendekatan kualitatif dan pendekatan kuantitatif. Jenis penelitian yang digunakan peneliti dalam penelitian ini adalah penelitian tindakan kelas.

Rancangan dalam penelitian ini menggunakan desain model Arikunto (2016: 42) : dimana terdapat 4 tahapan yaitu perencanaan, pelaksanaan, observasi, dan refleksi. Sedangkan subjek dalam penelitian ini seluruh siswa kelas IV SD Negeri 040550 Mardinding Kec. Mardingding Tahun Pembelajaran 2020/2021 yang berjumlah 30 orang siswa dan peneliti juga bekerjasama dengan wali kelas yang menjadi kolaborator dalam penelitan ini sebagai observer. Dan teknik dalam pengumpumpulan data yang digunakan yaitu tes dan observasi, dengan menggunakan analisis data kualitatif dan kuantitatif.

\section{HASIL DAN PEMBAHASAN PENELITIAN}

\section{Deskripsi Kondisi Awal}

Penelitian ini dilaksanakan di kelas IV SD Negeri 040550 Mardingding. Jenis penelitian yang digunakan adalah PTK (Penelitian Tindakan Kelas) dengan Penerapan Model Pembelajaran Problem Based Learning untuk meningkatkan hasil belajar siswa.

Pada tahap awal dilakukan observasi untuk mendapatkan informasi tentang pelaksanaan pembelajaran Tema Daerah Tempat Tinggalku dengan sub tema 1 Lingkungan Tempat Tinggalku di kelas IV SD Negeri 040550 Mardingding. Observasi dilakukan untuk memperoleh gambaran tentang pelaksanaan proses pembelajaran dan hasil belajar siswa. Nilai mata pelajaran Tema Daerah Tempat Tinggalku dengan sub sub tema 1 Lingkungan Tempat Tinggalku tersebut masih tergolong rendah sehingga perlu dilakukan tindakan perbaikan dengan menggunakan Model Pembelajaran Problem Based Learning pada sub tema 1 Lingkungan Tempat Tinggalku.

Penelitian ini dilaksanakan sebanyak 2 siklus yang meliputi perencanaan, pelaksanaan, observasi, dan refleksi. Dalam pelaksanaan penelitian ini, peneliti dan guru melakukan kerjasama, yang mana peneliti bertindak sebagai guru dan guru bertindak sebagai mengamati kegiatan guru dan siswa dalam proses belajar mengajar. Proses belajar mengajar bertujuan untuk meningkatkan hasil belajar siswa. Faktor penting yang merupakan salah satu penentu keberhasilan proses belajar siswa adalah model pembelajaran yang digunakan saat mengajarkan materi kepada siswa, artinya pembelajaran harus menarik dan tidak bersifat satu arah.

Peneliti melakukan pengamatan terhadap kondisi kelas saat guru menerangkan, peneliti mengamati guru mengajar tanpa menggunakan model pembelajaran. Langkah pertama yang dilakukan oleh peneliti adalah dengan mengamati cara guru kelas IV mengajar siswanya. Kemudian setelah melakukan pretest kepada siswa untuk mengetahui pemahaman awal siswa terhadap materi tematik tema Daerah Tempat Tinggalku dengan sub tema 1 Lingkungan Tempat Tinggalku maka sebelum tindakan yakni dengan 
2298 Peningkatan Hasil Belajar Siswa dengan Menggunakan Model Problem Based Learning pada

Pembelajaran Tematik - Emenina Br Tarigan, Ester J. Simarmata, Antonius Remigius Abi, Darinda Sofia

Tanjung

DOI: https://doi.org/10.31004/edukatif.v3i4.1192

menerapkan Model Pembelajaran Problem Based Learning dan untuk mengetahui gambaran-gambaran kesulitan yang dialami oleh siswa dalam menjawab soal dalam materi tema Daerah Tempat Tinggalku dengan sub tema 1 Lingkungan Tempat Tinggalku. Pre siklus ( tes awal) diberikan kepada siswa yakni 60 soal pilihan ganda.

Peneliti melakukan pengamatan terhadap kondisi kelas saat guru menerangkan, peneliti mengamati guru mengajar tanpa menggunakan model pembelajaran. Langkah pertama yang dilakukan oleh peneliti adalah dengan mengamati cara guru kelas IV mengajar siswanya. Kemudian setelah melakukan pre test kepada siswa untuk mengetahui pemahaman awal siswa terhadap materi tematik tema Daerah Tempat Tinggalku dengan sub tema 1 Lingkungan Tempat Tinggalku maka sebelum tindakan yakni dengan menerapkan Model Pembelajaran Problem Based Learning (PBL) dan untuk mengetahui gambaran-gambaran kesulitan yang dialami oleh siswa dalam menjawab soal dalam materi tema Daerah Tempat Tinggalku dengan sub tema 1 Lingkungan Tempat Tinggalku. Pre siklus ( tes awal) diberikan kepada siswa yakni 30 soal pilihan ganda.

Dari nilai hasil belajar atau ketuntasan belajar mulai dari Pretest, post tes siklus I dan post test siklus II, terlihat adanya peningkatan yang baik yang dicapai siswa. Peningkatan hasil belajar siswa pada setiap siklusnya dapat dilihat pada tabel dibawah ini.

\section{Perbandingan Hasil Belajar Secara klasikal Antar Siklus}

Berdasarkan data yang diperoleh dari hasil belajar siswa dalam pelaksanaan penelitian yang dimulai dari pelaksanaan post test siklus I, dan post test siklus II dapat dilihat bahwa terdapat peningkatan hasil belajar dari post test siklus I ke post test siklus II. Ketuntasan hasil belajar secara klasikal pada post test siklus I diperoleh sebesar 42,30\%. Pada post test siklus II ketuntasan hasil belajar meningkat menjadi 88,46\%. Peningkatan hasil belajar dari post test siklus I ke post test siklus II adalah sebesar 46,16\%. Untuk lebih jelasnya dapat dilihat pada diagram dibawah ini

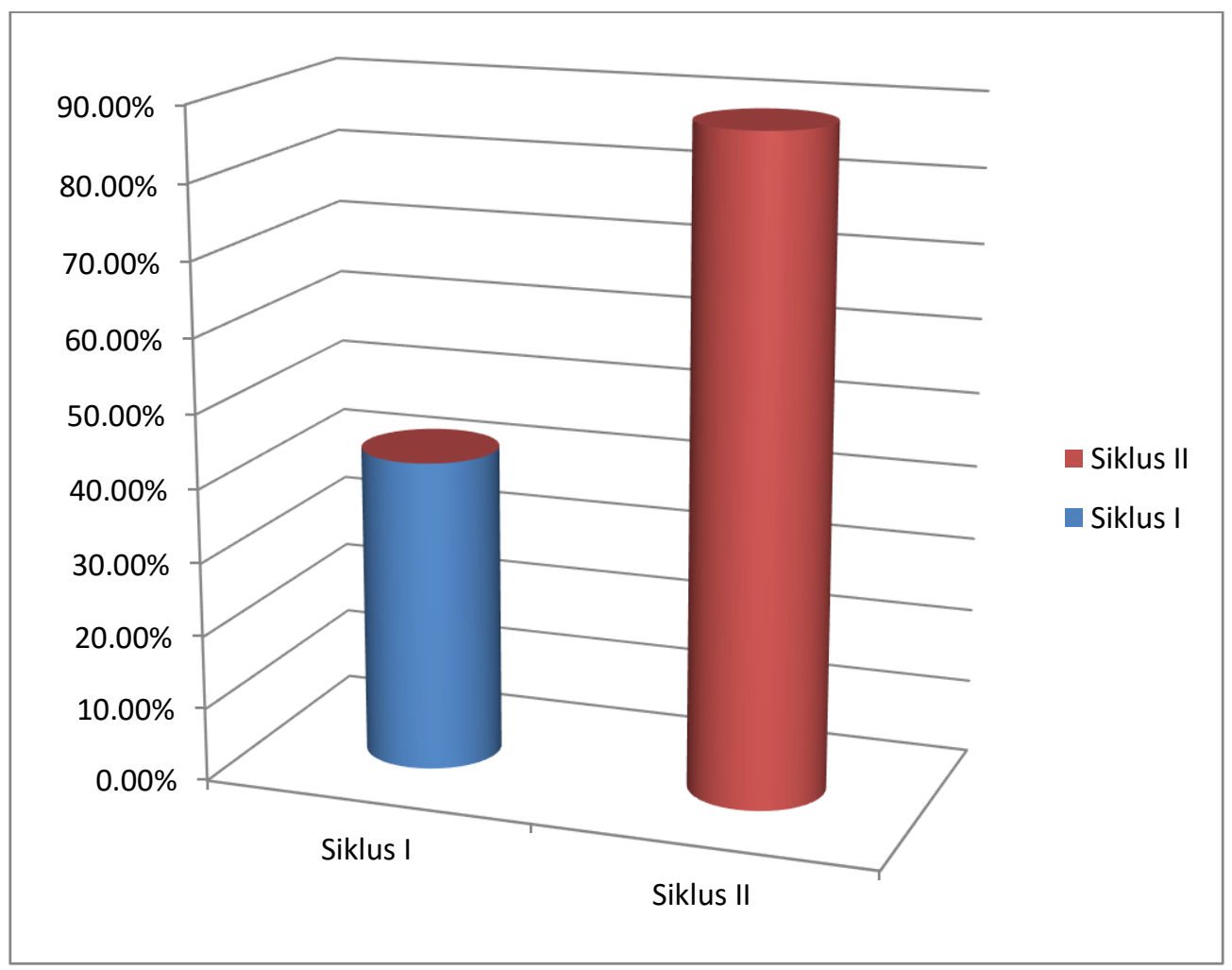

Gambar 1 Diagram Perbandingan Hasil Belajar Siswa Pada Post Test Siklus I 
2299 Peningkatan Hasil Belajar Siswa dengan Menggunakan Model Problem Based Learning pada

Pembelajaran Tematik - Emenina Br Tarigan, Ester J. Simarmata, Antonius Remigius Abi, Darinda Sofia

Tanjung

DOI: https://doi.org/10.31004/edukatif.v3i4.1192

\section{Perbandingan Rata-Rata Hasil Belajar Antar Siklus}

\section{dan Post Test Siklus II}

Berdarkan data yang diperoleh dari rata-rata hasil belajar pada post test siklus I dan post test siklus II dapat dilihat adanya peningkatan. Pada post test siklus I rata-rata hasil diperoleh sebesar 61,34 , sedangkan post test siklus II rata-rata hasil belajar meningkat menjadi 84,61 . Berdasarkan peningkatan yang diperoleh dari data hasil belajar siswa maka dapat dilihat bahwa dari post test siklus I ke post test siklus II mengalami peningkatan sebesar 23,27.

Untuk lebih jelas mengenai peningkatan rata-rata hasil belajar siswa dapat dilihat pada gambar diagram di bawah ini:

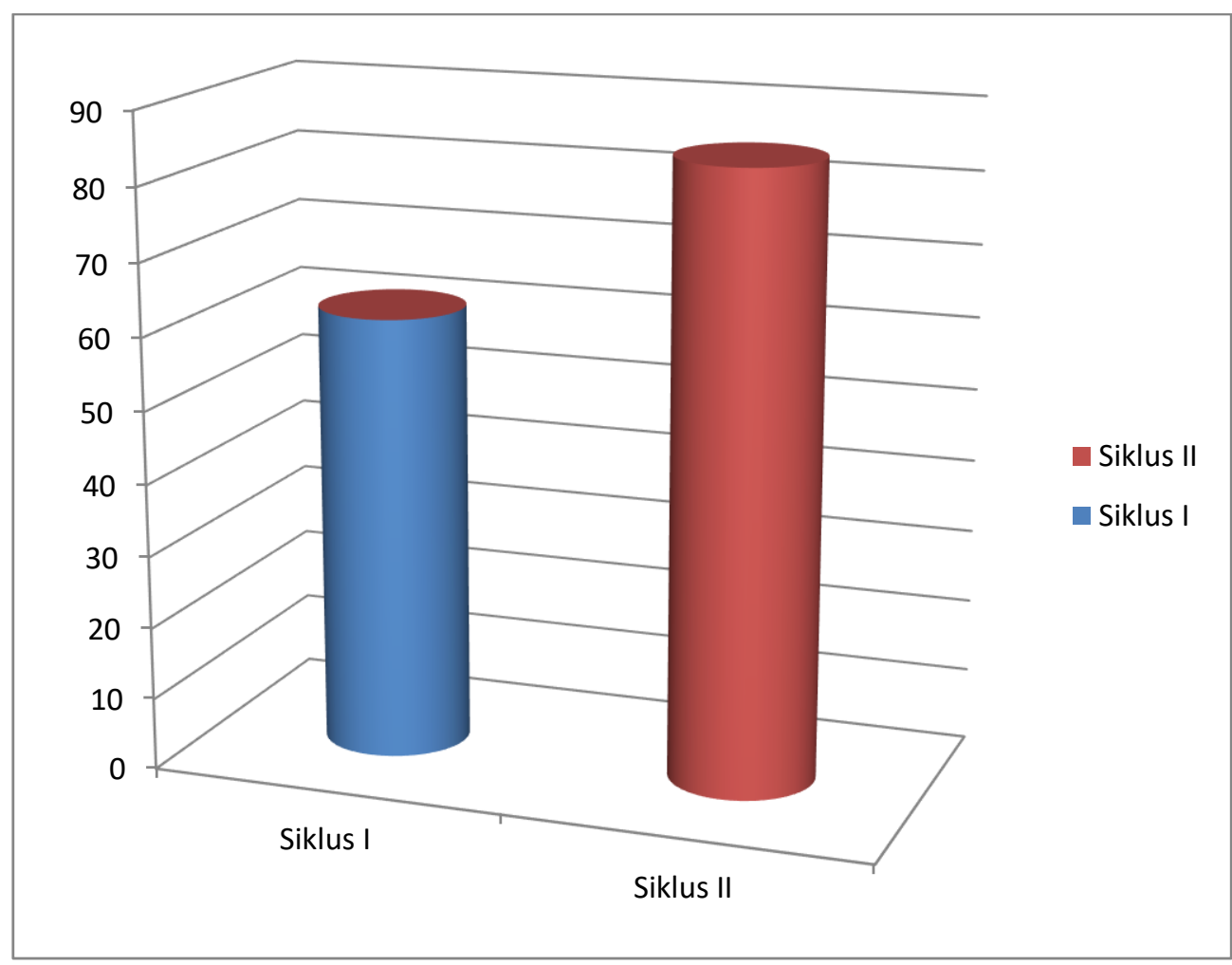

\section{Gambar 2 Diagram Perbandingan Rata-Rata Hasil Belajar Siswa Pada Post Test Siklus I Dan II}

\section{Pembahasan Hasil Penelitian}

Pada pembahasan ini akan diuraikan temuan penelitain yang telah dianalisis dan dideskripsikan sebelumnya. Adapun yang akan dibahas pada bagian ini yaitu tentang hasil observasi aktivitas guru, hasil observasi kegiatan siswa dan ketuntasan belajar siswa.

\section{Hasil Ketuntasan Belajar Siswa pada Siklus I dan II}

Hasil belajar siswa individual diperoleh pada penelitian tindakan kelas pra test, siklus I, dan siklus II, maka diperoleh perbandingan hasil belajar siswa individual yang diuraikan pada tabel dibawah ini:

Tabel 2 Perbandingan Hasil Belajar Siswa Individual

\begin{tabular}{llllll}
\hline \multirow{2}{*}{$\begin{array}{c}\text { No } \\
\text { Urut }\end{array}$} & \multirow{2}{*}{$\begin{array}{c}\text { Nama } \\
\text { Siswa }\end{array}$} & \multicolumn{3}{c}{ Nilai } & \multirow{2}{*}{ Keterangan } \\
\cline { 3 - 5 } & & Pra test & Siklus I & Siklus II nn & \\
\hline 1 & Angelita sabrina & 27 & 74 & 74 & Tetap \\
\hline 2 & April Br Sitepu & 53 & 34 & 87 & Meningkat \\
\hline 3 & Agnes Br Sembiring & 73 & 74 & 80 & Meningkat \\
\hline
\end{tabular}


2300 Peningkatan Hasil Belajar Siswa dengan Menggunakan Model Problem Based Learning pada Pembelajaran Tematik - Emenina Br Tarigan, Ester J. Simarmata, Antonius Remigius Abi, Darinda Sofia

Tanjung

DOI: https://doi.org/10.31004/edukatif.v3i4.1192

\begin{tabular}{|c|c|c|c|c|c|}
\hline 4 & Abdi Putra Ginting & 60 & 47 & 74 & Meningkat \\
\hline 5 & Bunga Br Tarigan & 73 & 80 & 87 & Tetap \\
\hline 6 & Ceristian & 43 & 34 & 47 & Tidak meningkat \\
\hline 7 & Diva Angreni & 73 & 47 & 87 & Meningkat \\
\hline 8 & Khetrin & 50 & 80 & 74 & Tetap \\
\hline 9 & Keisya & 76 & 80 & 80 & Tetap \\
\hline 10 & Lady febiola & 76 & 34 & 47 & Tidak Meningkat \\
\hline 11 & Marvel ginting & 53 & 47 & 80 & Meningkat \\
\hline 12 & Mikael & 27 & 60 & 67 & Tidak meningkat \\
\hline 13 & Muamar & 76 & 34 & 74 & Meningkat \\
\hline 14 & Muhamad arifah & 33 & 80 & 87 & Meningkat \\
\hline 15 & Muhamad Riski & 63 & 60 & 74 & Meningkat \\
\hline 16 & Mustofa & 70 & 80 & 87 & Meningkat \\
\hline 17 & Novena Br karo & 37 & 47 & 80 & Meningkat \\
\hline 18 & Prima Tarigan & 70 & 80 & 80 & Tetap \\
\hline 19 & Randie & 37 & 34 & 87 & Meningkat \\
\hline 20 & Rendy & 60 & 47 & 80 & Meningkat \\
\hline 21 & Revan & 60 & 80 & 74 & Tetap \\
\hline 22 & Reza Ginting & 73 & 80 & 87 & Meningkat \\
\hline 23 & Riski Sembiring & 27 & 60 & 47 & Tidak meningkat \\
\hline 24 & Tedy Sinulingga & 33 & 34 & 87 & Meningkat \\
\hline 25 & Thea & 27 & 47 & 80 & Meningkat \\
\hline 26 & Tito & 50 & 80 & 80 & Tetap \\
\hline 27 & Yeriko pinem & 33 & 60 & 74 & Meningkat \\
\hline 28 & Yohanes & 27 & 80 & 80 & Tetap \\
\hline 29 & Yosepa & 33 & 80 & 87 & Meningkat \\
\hline 30 & Janita br barus & 50 & 80 & 87 & Meningkat \\
\hline & Total & 1507 & 1834 & 2236 & \\
\hline & Rata-rata & $50,23 \%$ & $61,13 \%$ & $75 \%$ & \\
\hline
\end{tabular}

Berdasarkan tabel di atas dapat dinyatakan bahwa, pada pra test siswa yang tuntas belajar hanya 9 siswa, dan siswa yang tidak tuntas sebanyak 21 siswa dengan nilai rata-rata 50,23. Pada siklus I siswa yang tuntas sebanyak 14 siswa dan siswa yang tidak tuntas 16 siswa dengan nilai rata-rata 61,13. Selanjutnya karena hasil yang diperoleh belum mencapai indikator keberhasilan maka dilakukan siklus II. Pada siklus II siswa yang tuntas sebanyak 26 siswa dan siswa yang tidak tuntas hanya 4 siswa dengan nilai rata-rata 75. Perbandingan hasil belajar siswa individual pada pra test, siklus I dan siklus II dapat digambarkan dalam bentuk diagram di bawah ini:

Tabel 3 Hasil belajar siswa secara klasikal

\begin{tabular}{ccc}
\hline No & Jenis tes & Persentase ketuntasan klasikal \\
\hline $\mathbf{1}$ & Pre test & $50,23 \%$ \\
\hline 2 & Post test siklus I & $61,13 \%$ \\
\hline 3 & Post test siklus II & $75 \%$ \\
\hline
\end{tabular}

Hasil dari tabel 3 menunjukan bahwa nilai siswa mengalami peningkatan dari dilaksanakannya post test tiap siklus. Peningkatan hasil belajar siswa pada tema daerah tempat tinggalku sub tema aku bangga dengan daerah tempat tinggalku, ini dapat dilihat pada diagram di bawah ini: 
2301 Peningkatan Hasil Belajar Siswa dengan Menggunakan Model Problem Based Learning pada Pembelajaran Tematik - Emenina Br Tarigan, Ester J. Simarmata, Antonius Remigius Abi, Darinda Sofia Tanjung

DOI: https://doi.org/10.31004/edukatif.v3i4.1192

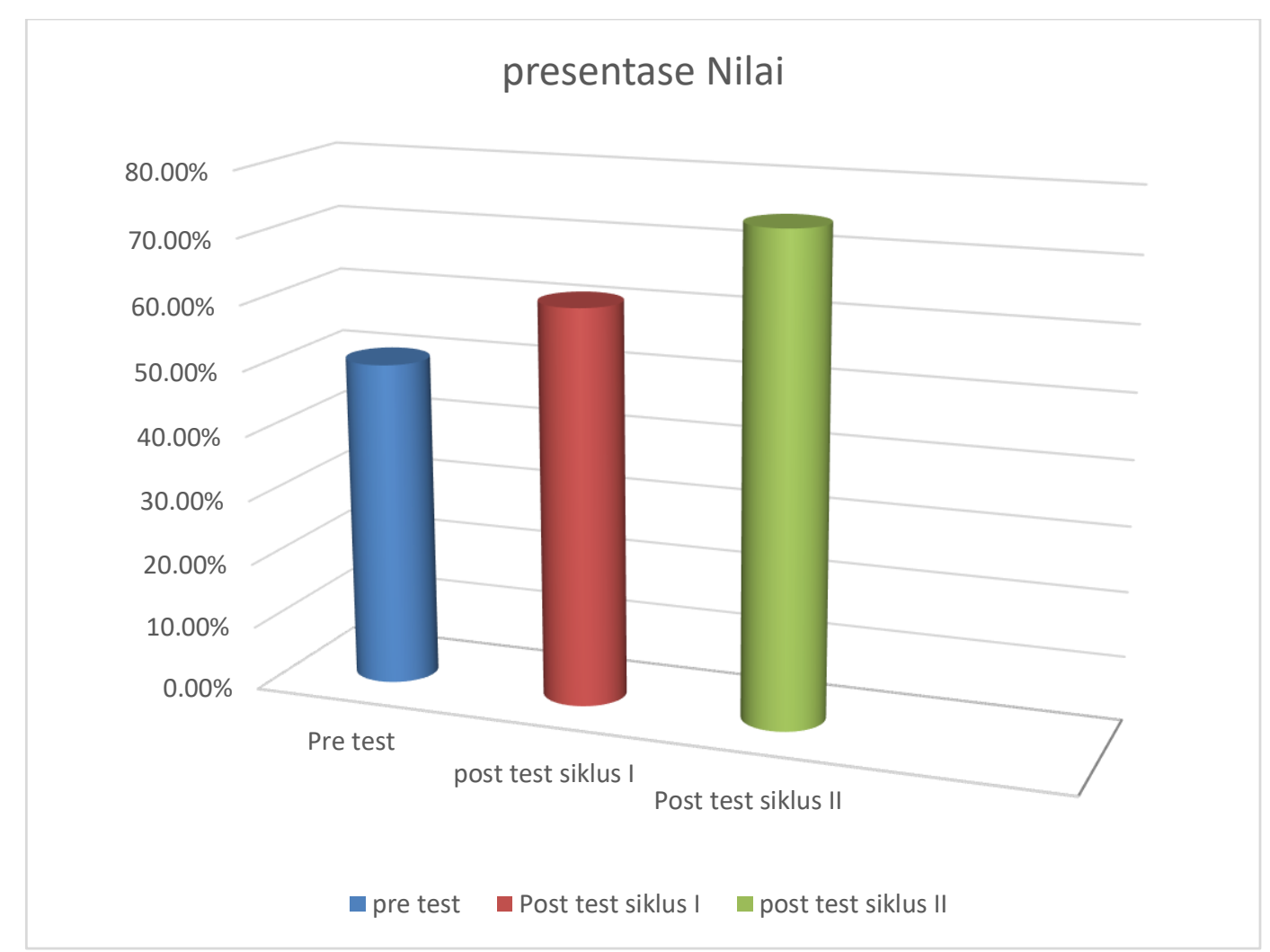

Gambar 3 Diagram Peningkatan Ketuntasan Hasil Belajar Siswa pada Pre Test, Post Test Siklus I dan Siklus II

Dari diagram di atas dapat dilihat bahwa pada pelaksanaan Pre Test 50,23\%. post test siklus I ketuntasan hasil belajar siswa diperoleh sebesar $61,13 \%$, tetapi ketuntasan hasil belajar ini belum mencapai kriteria ketuntasan klasikal yaitu 75\%. Siswa yang dikatakan tuntas atau mencapai Kriteria Ketuntasan Minimal (KKM) yaitu 70. Oleh karena itu, penelitian dilanjutkan ke siklus II. Pada post test siklus II hasil belajar siswa meningkat menjadi $75 \%$ dan mencapai kriteria ketuntasan klasikal, karena sudah mencapai kriteria ketuntasan klasikal maka peelitian ini tidak perlu dilanjutkan ke siklus III. Penelitian ini sudah berhasil.

\section{Hasil Observasi Aktivitas Guru Siklus I Dan II}

Berdasarkan data yang diperoleh dari observasi aktivitas guru pada siklus I dan siklus II hasil observasi aktivitas guru mengalami peningkatan. Hasil observasi aktivitas guru pada siklus I dan siklus II dapat dilihat pada tabel dibawah ini:

Tabel 4 Hasil Observasi Aktivitas Guru Siklus I Dan II

\begin{tabular}{ccccc}
\hline No & Siklus & Skor & Presentase & Kriteria \\
\hline 1 & siklus I & 28 & $56 \%$ & Cukup \\
\hline 2 & siklus II & 44 & $88 \%$ & Baik sekali \\
\hline
\end{tabular}

Dimana pada siklus I hasil observasi aktivitas guru diperoleh sebesar 56\% dengan kriteria cukup dan pada siklus II meningkat menjadi 88\% dengan kriteria baik. Berdasarkan peningkatan kedua siklus ini dapat dilihat bahwa dari siklus I ke siklus II terdapat peningkatan sebesar 32\%. Untuk lebih jelasnya dapat dilihat pada diagram di bawah ini: 
2302 Peningkatan Hasil Belajar Siswa dengan Menggunakan Model Problem Based Learning pada Pembelajaran Tematik - Emenina Br Tarigan, Ester J. Simarmata, Antonius Remigius Abi, Darinda Sofia Tanjung

DOI: https://doi.org/10.31004/edukatif.v3i4.1192

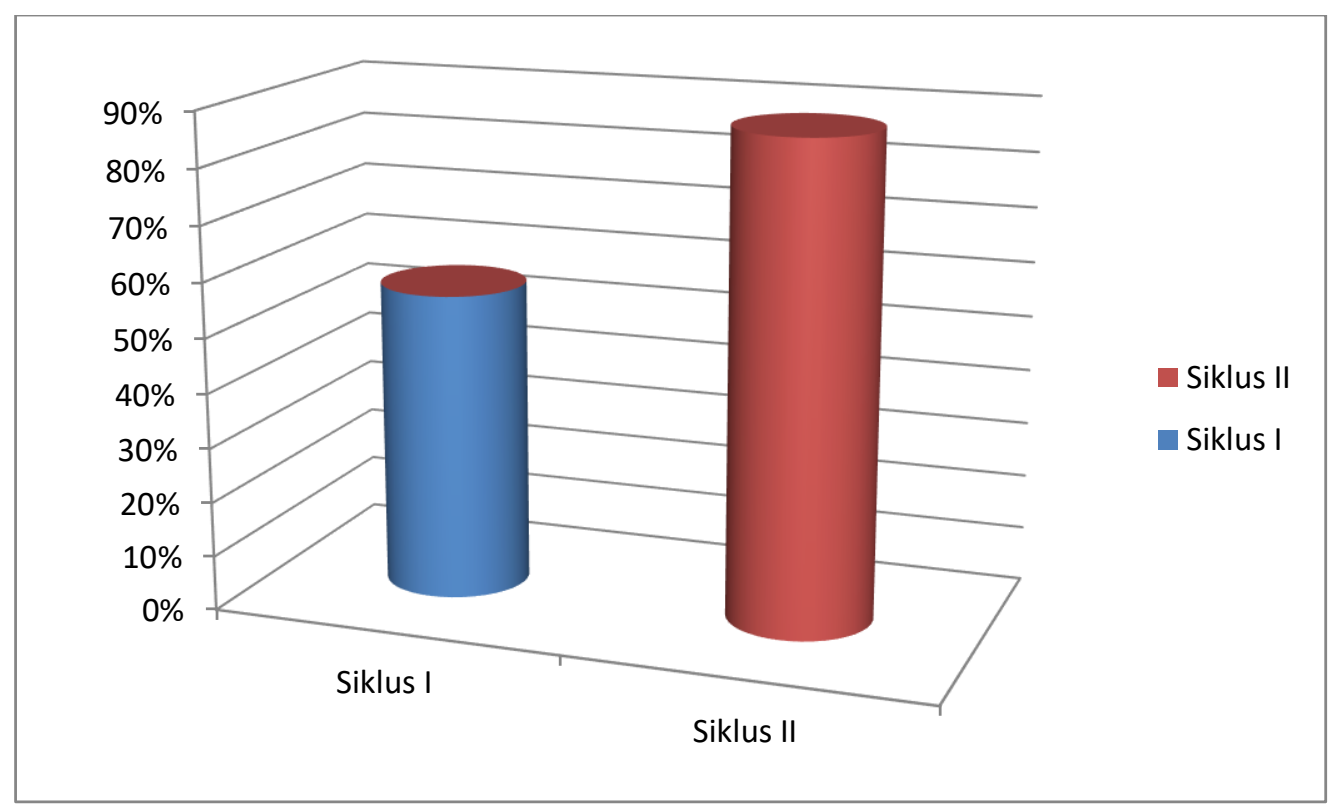

Gambar 4 Diagram Peningkatan Hasil Observasi Aktivitas Guru Pada Siklus I Dan II

\section{Hasil Observasi Aktivitas Siswa Siklus I dan II}

Dari hasil penelitian yang telah dilakukan peneliti diperoleh hasil aktivitas siswa yang dapat kita lihat pada tabel 5

Tabel 5 Hasil Observasi Aktivitas Siswa Siklus I Dan II

\begin{tabular}{ccccc}
\hline No & Siklus & Skor & Presentase & Kriteria \\
\hline 1 & siklus I & 30 & 60 & Cukup \\
\hline 2 & siklus II & 43 & 86 & Baik sekali \\
\hline
\end{tabular}

Berdasarkan tabel di atas pada siklus I hasil observasi aktivitas siswa diperoleh nilai sebesar 60 dengan kriteria cukup dan pada siklus II meningkat menjadi 86 dengan kriteria baik. Berdasarkan peningkatan kedua siklus ini dapat dilihat bahwa dari siklus I ke siklus II terdapat peningkatan sebesar 26.

Untuk lebih jelas mengenai peningkatan hasil dari observasi aktivitas guru dapat dilihat pada gambar diagram di bawah ini:

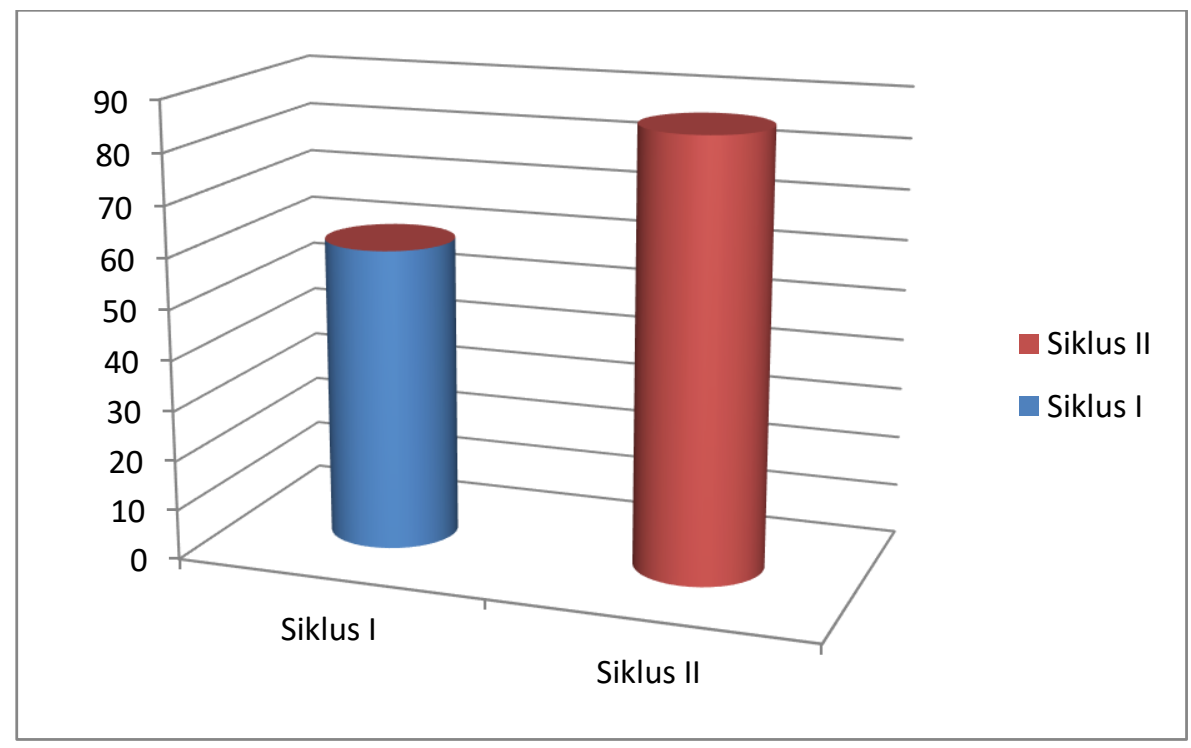


2303 Peningkatan Hasil Belajar Siswa dengan Menggunakan Model Problem Based Learning pada Pembelajaran Tematik - Emenina Br Tarigan, Ester J. Simarmata, Antonius Remigius Abi, Darinda Sofia Tanjung

DOI: https://doi.org/10.31004/edukatif.v3i4.1192

\section{Gambar 5 Diagram Hasil Observasi Aktivitas Siswa Siklus I dan II}

\section{KESIMPULAN}

Berdasarkan hasil penelitian dan pembahasan mengenai meningkatkan hasil belajar siswa dengan menggunakan model Problem Based Learning (PBL) pada tema Daerah Tempat Tinggalku di kelas IV SD Negeri 040550 Mardingding, dapat disimpulkan bahwa: data yang telah diperoleh peneliti dapat dilihat bahwa terdapat peningkatakan hasil belajar yang baik dari siklus I ke siklus II. Penelitian ini dikatakan berhasil apabila ketuntasan hasil belajar siswa secara klasikal mencapai 75\% dan pada siklus II diperoleh ketuntasan hasil belajar secara klasikal sebesar 75\%. Jadi dapat disimpulkan bahwa melalui temuan yang telah diperoleh peneliti dapat memberikan jawaban terhadap hasil belajar tema Daerah Tempat Tinggalku khususnya pada subtema Lingkungan Tempat Tinggalku.

\section{UCAPAN TERIMA KASIH}

Peneliti mengucapkan puji syukur keharirat Allah SWT karena karena rahmat dan karuniaNya yang berlimpah penulis dapat menyelesaikan artikel ini dengan baik. Penulis juga tidak lupa mengucapkan terima kasih kepada dosen pembimbing serta semua orang yang terlibat dalam penulisan artikel ini.

\section{DAFTAR PUSTAKA}

Aqib, Z., \& Dkk. (2016). Penelitian Tindakan Kelas Untuk Guru SD, SLB, Dan TK. Bandung:Yramawidya.

Arikunto, S., \& Dkk. (2017). Penelitian Tindakan Kelas. Jakarta: Bumi Aksara.

Dimyati, J. (2018). Pembelajaran Terpadu. Jakarta: Prenadamedia Group.

Fathurrohman, M. (2015). Model-Model Pembelajaran Inovatif. Yogyakarta: AR-Ruzz Media.

Handoko, O. (2018). Model Pembelajaran Problem Based Learning Dapat Meningkatkan Hasil Belajar Subtema Keberagaman Budaya Bangsaku. Journal For Lesson And Learning Studies, 1(3), 231-236. Https://Doi.Org/10.23887/Jlls.V1i3.15385

Istarani, \& Intan Pulungan. (2017). 58 Model Pembelajaran Inovatif. Medan: Media Persada.

Istarani, \& Pulungan, I. (2018). Ensiklopedi Pendidikan. Medan: Mediapersada.

Jihad, A., \& Haris, A. (2014). Evaluasi Pembelajaran. Yogyakarta: Multi Pressindo.

Majid, A. (2014). Pembelajaran Tematik Terpadu. Bandung: PT. Remaja Rodsakarya.

Novianti, A., Bentri, A., \& Zikri, A. (2020). Pengaruh Penerapan Model Problem Based Learning (Pbl) Terhadap Aktivitas Dan Hasil Belajar Siswa Pada Pembelajaran Tematik Terpadu Di Sekolah Dasar. Jurnal Basicedu, 4(1), 194-202. Https://Doi.Org/10.31004/Basicedu.V4i1.323

Nofziarni, A., Hadiyanto, H., Fitria, Y., \& Bentri, A. (2019). Pengaruh Penggunaan Model Problem Based Learning ( Pbl ) Terhadap Hasil Belajar Siswa Di Sekolah Dasar. Jurnal Basicedu, 3(4), 2016-2024. Https://Doi.Org/10.31004/Basicedu.V3i4.244

Prastowo, A. (2019). Analisis Pembelajaran Tematik Terpadu. Jakarta: Prenadamedia Group.

Putri, A., Firman, \& N. (2019). Hubungan Penggunaan Media Pembelajaran Tematik Terpadu Dalam Peningkatan Motif Altruistik Siswa Di Sekolah. Jurnal Ilmu Pendidikan, 1(3), 287-293. Https://Edukatif.Org/Index.Php/Edukatif/Index

Sari, R. P., Zuardi, Reinita, \& Zikri, A. (2020). Penggunaan Model Problem Based Learning Terhadap Hasil Belajar Siswa Sekolah Dasar. Jurnal Basicedu, 3(2), 524-532. 
2304 Peningkatan Hasil Belajar Siswa dengan Menggunakan Model Problem Based Learning pada Pembelajaran Tematik - Emenina Br Tarigan, Ester J. Simarmata, Antonius Remigius Abi, Darinda Sofia Tanjung

DOI: https://doi.org/10.31004/edukatif.v3i4.1192

Simorangkir, F. M. A., \& Tanjung, D. S. (2019). Pendekatan Multiple Intelligences Berbasis Budaya. Jurnal Education And Development, 7(4), 302-304.

Simorangkir, F. M. A., \& Tanjung, D. S. (2019b). Implementation Of Multiple Intelligences Approach Based On Batak Angkola Culture In Learning Thematic For Class IV SD Negeri 100620 Pargarutan Julu South Tapanuli District. Budapest International Research And Critics In Linguistics And Education (Birle) Journal, 2(4), 547-551. Https://Doi.Org/10.33258/Birle.V2i4.538

Situmorang, V. A. (2019). Pengaruh Model Pembelajaran Problem Based Learning Dan Model Pembelajaran Konvensional Terhadap Hasil Belajar Siswa Pada Mata Pelajaranmatematika Di Kelas V SDN 068003 P. Simalingkar Medan Tahun Pembelajaran 2018/2019. Juril AQUINAS, 2003(1), 22-43.

Slameto. (2017). Belajar Dan Faktor-Faktor Yang Mempengaruhinya. Jakarta : PT. Rineka Cipta.

Tanjung, D. S. (2016). Meningkatkan Hasil Belajar IPS Siswa Dengan Menerapakan Model Pembelajaran Kooperatif Tipe Team Game Tournament (TGT) Di Kelas V SDN 200111 Padangsidimpian. Jurna Juril AMIK MBP, 4(1), 68-79.

Utama, K. H., \& Kristin, F. (2020). Meta-Analysis Pengaruh Model Pembelajaran Problem Based Learning (PBL) Terhadap Kemampuan Berpikir Kritis IPA Di Sekolah Dasar. Jurnal Basicedu, 4(4), 889-898. Https://Doi.Org/10.31004/Basicedu.V4i4.482

Zuriati, E., \& Astimar, N. (2020). Peningkatan Hasil Belajar Pada Pembelajaran Tematik Terpadu Menggunakan Model Problem Based Learning Di Kelas IV SD ( Studi Literatur ). Jurnal Pendidikan Tambusai, 4(3), 2071-2082. 